\title{
Using Rapid Prototyping Data to Enhance a Knowledge-Based Framework for Product Redesign
}

\author{
Stefano FILIPPI ${ }^{1}$, Ilaria CRISTOFOLINI ${ }^{2}$ \\ ${ }^{1}$ DIEGM Department, University of Udine, Viale delle Scienze Udine, Italy \\ ${ }^{2}$ DIMS Department, University of Trento, Via Mesiano Trento, Italy \\ Email:filippi@uniud.it, Ilaria.Cristofolini@ing.unitn.it
}

\begin{abstract}
The particular characteristics of Rapid Prototyping technologies, both in terms of constrains and opportunities, often require the reconfiguration of the product model to obtain the best compliance with the product functionalities and performances. Within this field of research, a knowledge-based tool named Design GuideLines Collaborative Framework (DGLs-CF) was developed to support both the designers defining the product consistently with the manufacturing technologies and the manufacturers defining the building setup consistently with the product requirements. Present work is focused on enhancing the DGLs-CF knowledge base and on updating the DGLs-CF knowledge management by using the information gathered on some RP technologies. The added-value of this research is represented by an improvement in the Redesign/Reconfiguration Package, the final result of the DGLs-CF adoption. This is a list of actions to be performed on the product model and on the process parameters to avoid the limitations of the technology and to exploit at best its opportunities.
\end{abstract}

Keywords: rapid prototyping, knowledge-based engineering, product redesign, collaborative engineering

\section{Introduction}

The increasing complexity of design tasks and continuous developments in technology require the improvement of designers' problem-solving capabilities, through the development of Design for X (DfX) methods and tools accordingly. Moreover, they must be flexible enough to allow an easy customization according to the evolution of the technologies that they address. Up to now, several examples of DfX appeared in the research landscape, as described in [1-11] The next research step was to investigate the possibility of merging several DfXs together in an integrated framework able to generate design guidelines related to more than one phase of the product lifecycle. In this context, the Design GuideLines Collaborative Framework (DGLs-CF) was developed as a knowledge-based tool to help designers defining the product consistently with manufacturing and verification technologies. The aim of the DGLs-CF is to evaluate the feasibility of the product (model) with available manufacturing technologies, to exploit the particular characteristics of them and to measure the conformity of the product to the requirements with specific verification technologies [12].
Purpose of this work is enhancing the DGLs-CF knowledge base and updating the DGLs-CF knowledge management by exploiting the information related to several Rapid Prototyping (RP) technologies. The goal is to generate richer and more effective guidelines information for the designers. RP technologies build physical models starting directly from their CAD representations, as this way costs and times are drastically reduced. They are a very powerful tool in product development. New products normally develop in Concurrent Engineering environments where many actors play different roles; in these scenarios it is of great help having a physical prototype of the product, something tangible, which may help communicating different skills and developing new ideas $[2,13-20]$. The specific characteristics of the RP technologies, however, are not so widely known in depth and thus it is worthwhile customizing the DGLs-CF for them. This may be a good way of helping non-expert designers in exploiting the opportunities of RP technologies.

The paper opens with a short description of the DGLs$\mathrm{CF}$ and then goes on to describe the four RP technologies selected for this research. The core section of the paper concerns the data collection and their elaboration to get 
compatibility with the knowledge base format inside the DGLs-CF. Some considerations about the use of these new pieces of information relating with specific classes of products close the paper.

\section{The DGLs-CF}

The DGLs-CF is a decision support methodology aimed at effectively helping and leading the activities of designers, manufacturers and inspectors for product redesign and process reconfiguration. The initial consideration is that designers are not necessarily experts in manufacturing and verification processes; likewise, manufacturers and inspectors are not experts in design. A detailed description of the DGLs-CF appears in [12,21-23]The DGLs-CF structure is shortly described in the next paragraph using IDEF0 formalism [24]. IDEF0 is preferred to more sophisticated description methods (UML, for example) because its simplicity makes it a good tool for sharing information in a concurrent engineering environment, especially for non-expert users.

\subsection{The DGLs-CF Roadmap}

Shortly speaking, the DGLs-CF considers the set of available technologies and the product to be redesigned and suggests a list of actions - the Redesign/Reconfiguration Package - to get the best compatibility.

The easiest way to describe this methodology is by using the so-called DGLs-CF roadmap. It puts in the correct logical order all the activities required by the DGLs-CF adoption as well as the related algorithms and modules. Figure 1 shows the main level of the IDEF0 diagram.

In the first setup phase (A1), the DGLs-CF is customized considering the characteristics of the class of the available manufacturing and verification technologies as well as the features characterising the product under study. Technological characteristics and product features are then related to each other using rules, which relate the limitations (but sometimes also the opportunities) of the technologies to each product feature. Rules are coupled with expressions, which are needed to evaluate

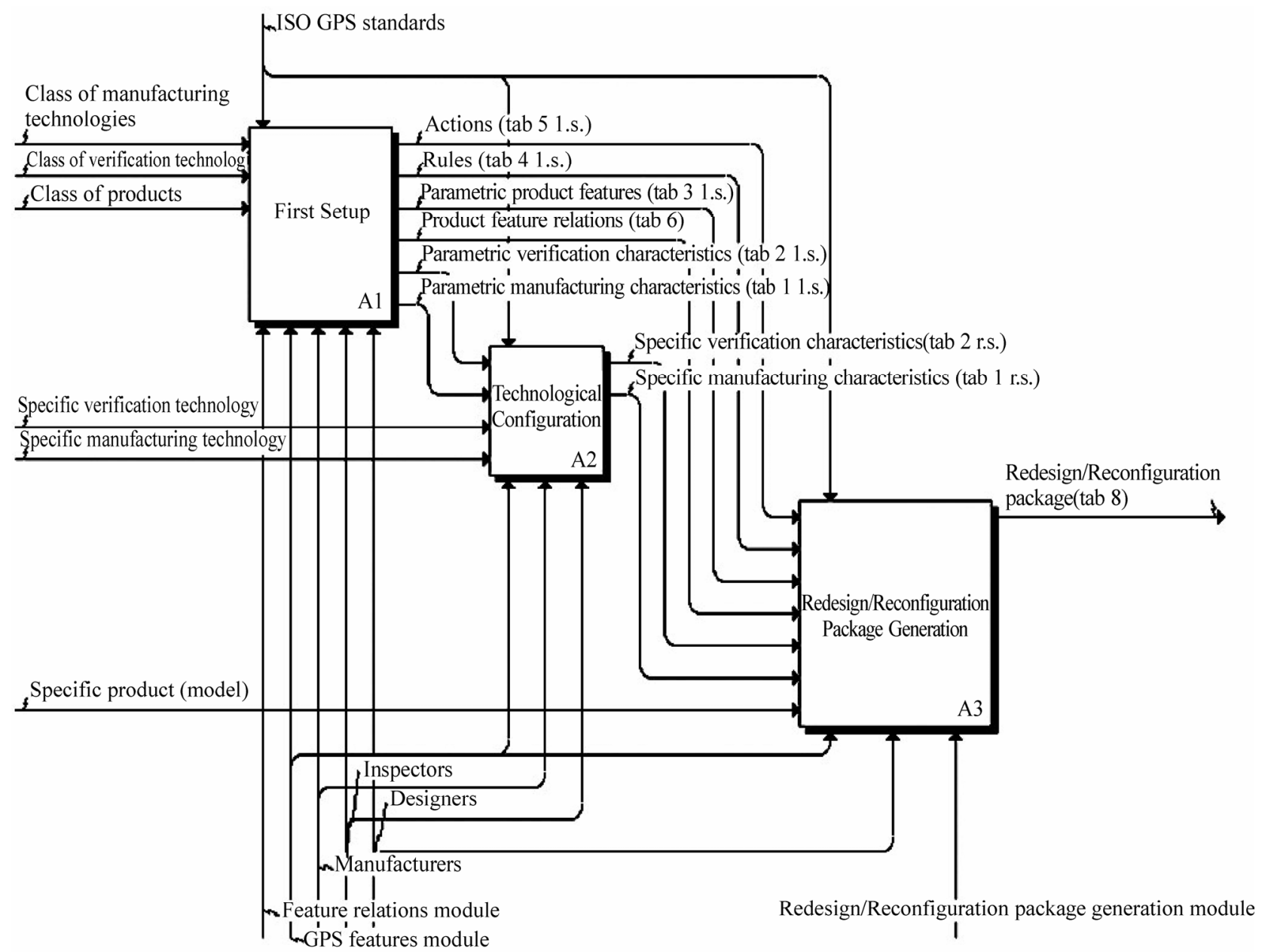

Figure 1. Main level of the IDEF0 diagram of the DGLs-CF roadmap 
quantitatively the compatibility of the existing version of the product (model) with the available technologies. When the compatibility is not present, the rules suggest actions to be executed to overcome the limitations of the technologies and to exploit their opportunities. It must be noted that some actions may also affect different features when they are performed on a single feature to gain its compatibility. A "dynamic coefficient" is thus associated to the actions, with its value determined by the amount of features the action may affect. This value is decisive in defining the sequence of actions during the generation of the Redesign/Reconfiguration Package.

The Technological Configuration phase (A2) allows to set the parameter values of the manufacturing and verification characteristics, given the specific brands/models of the available equipments.

Finally, the Redesign/Reconfiguration Package Generation phase (A3) generates the list of actions (the Redesign/Reconfiguration Package) to be applied to the product (model) and to the technological process parameters by means of a recursive algorithm that evaluates time by time different product (model) configurations.

In this work the DGLs-CF knowledge base is enhanced with information related to some RP technologies; for this reason the main characteristics of the RP technologies considered here are described in the following.

\section{RP Technologies}

The RP technologies considered here are Fused Deposition Modelling (FDM), Stereolithography (SLA), Selective Laser Sintering (SLS), and Laminated Object Manufacturing (LOM). All of these systems build parts in multiple thin layers and their main characteristics, which are used in the DGLs-CF customisation, are summarised hereafter [25-27].

\subsection{Fused Deposition Modelling (FDM)}

This technology extrudes a molten thermoplastic filament (ABS, polyolefin, polyamide...) through a nozzle in the form of a thin ribbon and delivers it in computercontrolled locations appropriate for the object geometry, thus building the sections of the part. No high powered lasers are used. Typically, the delivery head moves in the horizontal plane while the support plane, where the part is built, moves vertically, so that each section is built over the previous one. The application temperature is such that the applied material bonds firmly with the previous layer. Some support material may be necessary to build the model, depending on the geometrical complexity of the part and on its orientation inside the workspace.
The quantity and the shape of the support, which has to be removed from the final part, are calculated automatically. The first section is always built on a support plane, which section is slightly larger than the model to allow an easy removal of the part from the building platform. Precision and surface finishing of the parts are affected by the so-called"slicing" (the layering), which depends on the kind of equipment used, and can vary typically from $0.17 \mathrm{~mm}$ to $0.33 \mathrm{~mm}$. The final parts do not need post-processing, except for support removal and some grinding for a better surface finishing.

\subsection{Stereolithography (SLA)}

A platform that can be lowered and elevated is usually located the thickness of a layer below the surface of a liquid photosensitive polymer contained in a tank. Each slice is etched onto the surface of the photosensitive polymer that solidifies when exposed to the laser beam. Once the laser has covered the whole surface of the layer, the platform lowers to a depth of another layer thickness, allowing the liquid resin to flow over the previously cured layer. A re-coating blade passes over the surface to ensure that a consistent layer thickness is present before the beginning of the next layer. Different building styles for the prototypes can be used with a SLA system. Normal style involves building full resin prototypes while other styles leaves some resin in the liquid state for different purposes (stresses minimization, generation of models for investment casting, etc.). Supports are required when islands (portion of a layer that is disconnected from any other portion of the same layer), overhangs, or cantilevered sections exist in the part being built. SLA parts have good surface texture and dimensional accuracy, however the orientation of the model in the workspace (due to the staircase effect) and the presence of support can influence the surface finishing. At the end of the building phase the model is carefully removed from the platform and a post-curing phase is performed, in a UV-beam oven, to completely solidify the part.

\subsection{Selective Laser Sintering (SLS)}

Here the object is built over a platform, where a layer of plastic, metal or ceramic powder (particle size approximately $50 \mu \mathrm{m}$ ) is spread and kept heated. A laser beam melts the powder particles selectively. As the layer is finished, the platform moves down by the thickness of one layer (approximately $0.10-0.15 \mathrm{~mm}$ ), and a new layer of powder is spread on the previous one. When the laser exposes the new layer, it melts and bonds to the previous one. The process repeats until the part is complete. Surrounding powder particles act as supporting 
material for the objects but in any case additional structures are needed during the building of overhangs. SLS parts have average surface texture and dimensional accuracy, the quality being mainly influenced by the powder particle size. On completion, the built volume has to cool down to room temperature after which the processed objects can be removed from the powder bed by brushing away excess powder. Sandblasting or other finishing manufacturing techniques are used to remove all un-sintered particles and to improve the final accuracy of the sintered objects. Of course in this case the support removal is not straightforward and requires special machining and tools.

\subsection{Laminated Object Manufacturing (LOM)}

In this technology, a sheet of thick paper (coming from a feed roll) with a polyethylene coating on the reverse side is placed on a platform. The coating is melted by a heated roller making the paper adhere to the building platform that, just like the technologies described before, can lower and lift along the $\mathrm{Z}$ axis. A laser then cuts the paper following the boundaries of the section of the object. The laser also creates hatch marks, which generate a collection of cubes in the final building volume of glued paper. These cubes behave as a support structure for the overhangs of the model. When the laser has finished the layer, a new paper sheet is applied. At the end of the job, the model is captured within a block of paper. When all of the surrounding cubes have been removed, the unfinished part is sanded down. In the case of cavities problems could be faced in the removal of the paper cubes.

The natural sensitivity of the paper to humidity and temperature can be reduced by coating the model. The surface finishing and the accuracy of the model are not to the same standard as the other methods, however objects have the look and feel of wood and thus can be worked and finished like wood.

\section{DGLs-CF Knowledge Base Enhancement}

\subsection{Collection of Data}

The aim of this work is the enhancement of the DGLsCF knowledge base with pieces of information coming from the RP field. The attention is focused on the manufacturing characteristics, in order to determine the compatibility between the RP technologies and the products. Interviews with expert users and to equipment manufacturers, the previous experience of the authors, papers, user manuals and brochures, etc., have been the sources used for data collection. The goal of this task is to collect the characteristics of the four RP technologies described previously and to identify the related parameters that will be used afterwards by the DGLs-CF users to describe the available equipments [28-38].

\subsection{Insertion of Data in the DGLs-CF}

The DGLs-CF data structure is organized in tables. Those concerned with in this research have a left side where the characteristics of the class of technology and the related parameters are listed and a right side where the values of the parameters are set, given the specific available equipment. In this research, only the left side is considered, given that the goal is to characterize classes of RP technologies and not specific equipments. The information concerning the four RP technologies considered in this paper are inserted in the DGLs-CF data structure, the result is reported in Table 1 (FDM), Table 2 (SLA), Table 3 (SLS), and Table 4 (LOM).

Some characteristics are common to all the RP technologies considered, as they are intrinsic to the "nature" of the technologies themselves, these being the volume of the manufacturing workspace, the slicing (all the technologies build the models by layers) and the kind of material. Another important issue to consider in determining the compatibility between the RP technology and the product is the need for support for all of them, except for the LOM. SLA and SLS also allow the definition of the building style, as hatching and contouring style, and this characteristic also affects the product features.

\section{Discussion}

The outcomes of the activities described previously are presented here as an overview of the added-value of this result of this research inside the DGLs-CF. As seen before, in the DGLs-CF all the technological characteristics and the product features are expressed in terms of the related parameters. These features are described in the DGLs-CF data structure in another important table where again the left side contains the parameters allowing to describe a class of products, while the right side is filled by the parameter values of the specific product under study. The analysis of the RP parameters of Tables 1,2,3, and 4 suggests to identify some classes of products, which can be specifically considered here to highlight the enhancement in the DGLs-CF knowledge base. Table 5 shows the collected product features describing plastic front covers, Table 6 for headlights, Table 7 for moulds for headlights and Table 8 for dashboards. The right side of these tables is different from the technology-related ones as there is more than one column to highlight that the information processing in the DGLs-CF comes in an 
Table 1. Parametric manufacturing characteristics for the FDM technology

\begin{tabular}{|c|c|c|c|}
\hline \multicolumn{4}{|r|}{ Characteristic } \\
\hline Label & Name & Description & Parameters \\
\hline M1 & Workspace & $\begin{array}{l}\text { Volume of the manu- } \\
\text { facturing workspace }\end{array}$ & $\begin{array}{c}\text { Workspace_x, Workspace_y, Workspace_z: dimensions } \\
\text { of the manufacturing workspace }\end{array}$ \\
\hline \multirow[t]{2}{*}{ M2 } & \multirow[t]{2}{*}{ Material } & \multirow[t]{2}{*}{ Kind of material used } & 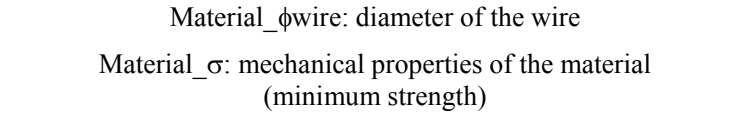 \\
\hline & & & $\begin{array}{l}\text { Material_tx, Material_ty, Material_tz: dimensional } \\
\text { tolerances related to the material }\end{array}$ \\
\hline \multirow{3}{*}{ M3 } & \multirow{3}{*}{ Slicing } & \multirow{3}{*}{$\begin{array}{l}\text { Material deposed slice } \\
\text { by slice }\end{array}$} & Slicing_zmin: minimum thickness of the slice \\
\hline & & & 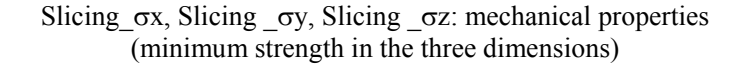 \\
\hline & & & Slicing_Ra_z: minimum obtainable roughness in $\mathrm{z}$ direction \\
\hline \multirow{3}{*}{ M4 } & \multirow{3}{*}{ Support } & \multirow{3}{*}{$\begin{array}{l}\text { Support needed when } \\
\text { building overhangs/ } \\
\text { sloped surfaces or } \\
\text { cavities }\end{array}$} & Support_x, Support_y, Support_z: support dimensions \\
\hline & & & $\begin{array}{c}\text { Support_ } \alpha: \text { critical angle for supports removal (angle between the } \\
\text { vertical wall and the overhang) }\end{array}$ \\
\hline & & & Support_Ra_xy: minimum obtainable roughness in xy plane \\
\hline
\end{tabular}

\begin{tabular}{|c|}
\hline $\begin{array}{c}\text { Parameter values of the } \\
\text { specific available } \\
\text { equipment }\end{array}$ \\
\hline $\begin{array}{l}\text { Workspace_x }=\ldots \\
\text { Workspace_y }=\ldots \\
\text { Workspace_z }=\ldots\end{array}$ \\
\hline Material_ $\phi$ wire $=\ldots$ \\
\hline Material_ $\sigma=\ldots$ \\
\hline $\begin{array}{l}\text { Material_tx }=\ldots \\
\text { Material_ty }=\ldots \\
\text { Material_tz }=\ldots\end{array}$ \\
\hline Slicing_zmin $=\ldots$ \\
\hline $\begin{array}{l}\text { Slicing_} \sigma x=\ldots \\
\text { Slicing__} \sigma y=\ldots \\
\text { Slicing_} \sigma z=\ldots\end{array}$ \\
\hline Slicing_Ra_z $=\ldots$ \\
\hline $\begin{array}{l}\text { Support_x }=\ldots \\
\text { Support_y }=\ldots \\
\text { Support_z }=\ldots\end{array}$ \\
\hline Support_ $\alpha=\ldots$ \\
\hline Support_Ra_xy $=\ldots$ \\
\hline
\end{tabular}

Table 2. Parametric manufacturing characteristics for the SLA technology

\begin{tabular}{|c|c|c|c|}
\hline \multicolumn{4}{|r|}{ Characteristic } \\
\hline Label & Name & Description & Parameters \\
\hline M1 & Workspace & $\begin{array}{l}\text { Volume of the } \\
\text { manufacturing } \\
\text { workspace }\end{array}$ & $\begin{array}{c}\text { Workspace_x, Workspace_y, Workspace_z: dimensions } \\
\text { of the manufacturing workspace }\end{array}$ \\
\hline \multirow{2}{*}{ M2 } & \multirow{2}{*}{ Material } & \multirow[t]{2}{*}{$\begin{array}{l}\text { Kind of material } \\
\text { used }\end{array}$} & $\begin{array}{l}\text { Material_o: mechanical properties of the material (minimum strength) } \\
\text { Material_Ra_xy: minimum obtainable roughness in xy plane } \\
\text { related to the material }\end{array}$ \\
\hline & & & $\begin{array}{c}\text { Material_tx, Material_ty, Material_tz: dimensional tolerances } \\
\text { related to the material }\end{array}$ \\
\hline \multirow{3}{*}{ M3 } & \multirow{3}{*}{ Slicing } & \multirow{3}{*}{$\begin{array}{l}\text { Material deposed } \\
\text { slice by slice }\end{array}$} & Slicing_zmin: minimum thickness of the slice related to slicing \\
\hline & & & 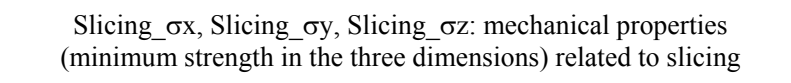 \\
\hline & & & $\begin{array}{c}\text { Slicing_Ra_z: minimum obtainable roughness in } \mathrm{z} \text { direction } \\
\text { related to slicing }\end{array}$ \\
\hline \multirow{3}{*}{ M4 } & \multirow{3}{*}{ Support } & \multirow{3}{*}{$\begin{array}{c}\text { Support needed } \\
\text { when building } \\
\text { overhangs/sloped } \\
\text { surfaces or cavi- } \\
\text { ties }\end{array}$} & Support_x, Support_y, Support_z: support dimensions \\
\hline & & & $\begin{array}{c}\text { Support_ } \alpha \text { : critical angle for supports removal (angle between the } \\
\text { vertical wall and the overhang) }\end{array}$ \\
\hline & & & Support_Ra_xy: minimum obtainable roughness in xy plane \\
\hline \multirow{3}{*}{ M5 } & \multirow{3}{*}{$\begin{array}{l}\text { Building } \\
\text { style }\end{array}$} & \multirow{3}{*}{$\begin{array}{l}\text { Different building } \\
\text { styles }\end{array}$} & 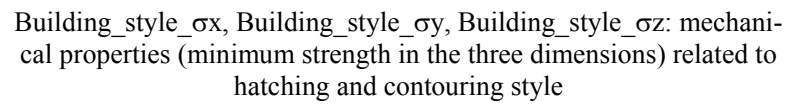 \\
\hline & & & $\begin{array}{l}\text { Building_style_Ra_xy: minimum obtainable roughness in xy plane } \\
\text { related to hatching and contouring style }\end{array}$ \\
\hline & & & $\begin{array}{l}\text { Building_style_Ra_z: minimum obtainable roughness in z } \\
\text { direction related to hatching and contouring style }\end{array}$ \\
\hline
\end{tabular}

Parameter values of the specific available equipment

Workspace_x $=\ldots$

Workspace $\mathrm{y}=\ldots$

Workspace $\_$z $=\ldots$

Material_ $\sigma=\ldots$

Material_Ra_xy=...

Material_tx $=\ldots$.

Material_ty $=\ldots$

Material_tz $=\ldots$

Slicing_zmin $=\ldots$

Slicing_ $\sigma \mathrm{x}=\ldots$

Slicing $\sigma y=\ldots$

Slicing_ $\sigma z=\ldots$

Slicing_Ra_z $=\ldots$

Support_ $\mathrm{x}=\ldots$

Support_y $=\ldots$

Support_ $z=\ldots$

Support_ $\alpha=\ldots$

Support_Ra_xy=...

Building_style_ $\sigma x=\ldots$

Building_style_ $\sigma y=\ldots$

Building_style_oz $=\ldots$

Building_style_Ra_xy $=$..

Building_style_Ra_z $=\ldots$ 
Table 3. Parametric manufacturing characteristics for the SLS technology

\begin{tabular}{|c|c|c|c|}
\hline \multicolumn{4}{|r|}{ Characteristic } \\
\hline Label & Name & Description & Parameters \\
\hline M1 & Workspace & $\begin{array}{l}\text { Volume of the } \\
\text { manufacturing } \\
\text { workspace }\end{array}$ & $\begin{array}{c}\text { Workspace_x, Workspace_y, Workspace_z: dimensions of the } \\
\text { manufacturing workspace }\end{array}$ \\
\hline M2 & Material & $\begin{array}{l}\text { Kind of material } \\
\text { used }\end{array}$ & $\begin{array}{l}\text { Material_zmin: minimum thickness of the slice related to the particle size } \\
\text { Material_o: mechanical properties of the material (minimum strength) } \\
\text { Material_Ra_xy: minimum obtainable roughness in xy plane related to the } \\
\text { particle size }\end{array}$ \\
\hline M3 & Slicing & $\begin{array}{l}\text { Material deposed } \\
\text { slice by slice }\end{array}$ & 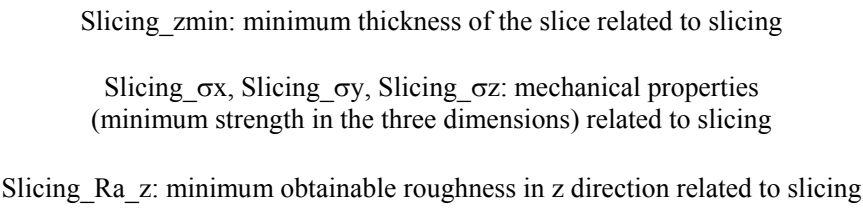 \\
\hline M4 & Support & $\begin{array}{l}\text { Support needed } \\
\text { when building } \\
\text { overhangs/sloped } \\
\text { surfaces or cavities }\end{array}$ & $\begin{array}{l}\text { Support_x, Support_y, Support_z: support dimensions } \\
\text { Support_ } \alpha \text { : critical angle for supports removal } \\
\text { (angle between the vertical wall and the overhang) } \\
\text { Support_Ra_xy: minimum obtainable roughness in xy plane }\end{array}$ \\
\hline M5 & $\begin{array}{l}\text { Building } \\
\text { style }\end{array}$ & $\begin{array}{l}\text { Different building } \\
\text { styles }\end{array}$ & 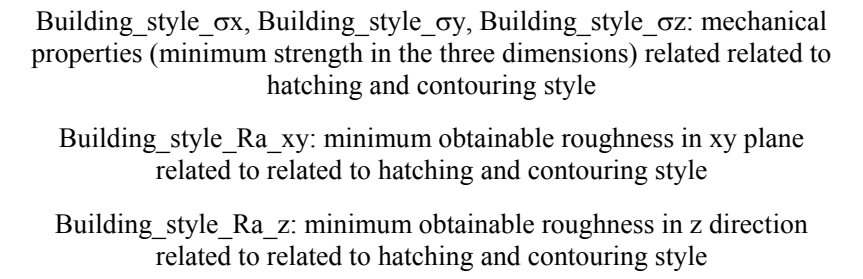 \\
\hline
\end{tabular}

Parameter values of the specific available equipment

Workspace $\mathrm{x}=\ldots$ Workspace $\_\mathrm{y}=\ldots$ Workspace $\mathrm{Z}=$....

Material_zmin $=\ldots$

Material_ $\sigma=$. .

Material_Ra_xy $=\ldots$

Slicing_zmin $=\ldots$

Slicing_ $\sigma \mathrm{x}=\ldots$

Slicing_ $\sigma y=\ldots$

Slicing_ $\sigma \mathrm{z}=\ldots$

Slicing_Ra_z $=$...

Support $\mathrm{x}=\ldots$

Support_y $=.$. .

Support $\mathrm{z}=\ldots$

Support_ $\alpha=\ldots$

Support_Ra_xy $=\ldots$.

Building_style_ $\sigma x=\ldots$ Building style $\sigma y=\ldots$ Building_style_ $\sigma \mathrm{z}=\ldots$

Build-

ing_style_Ra_xy $=\ldots$

Build-

ing_style_Ra_z $=$...

Table 4. Parametric manufacturing characteristics for the LOM technology

\begin{tabular}{|c|c|c|c|c|}
\hline \multicolumn{4}{|r|}{ Characteristic } & \multirow{2}{*}{$\begin{array}{c}\text { Parameter values of } \\
\text { the specific available } \\
\text { equipment }\end{array}$} \\
\hline Label & Name & Description & Parameters & \\
\hline M1 & Workspace & $\begin{array}{l}\text { Volume of the } \\
\text { manufacturing } \\
\text { workspace }\end{array}$ & $\begin{array}{l}\text { Workspace_x, Workspace_y, Workspace_z: dimensions } \\
\text { of the manufacturing workspace }\end{array}$ & $\begin{array}{l}\text { Workspace } \mathrm{x}=\ldots \\
\text { Workspace_y }=\ldots \\
\text { Workspace_z }=\ldots\end{array}$ \\
\hline \multirow{4}{*}{ M2 } & \multirow{4}{*}{ Material } & \multirow{4}{*}{$\begin{array}{l}\text { Kind of material } \\
\text { used }\end{array}$} & $\begin{array}{l}\text { Material_zmin: minimum thickness of the slice related to } \\
\text { the paper thickness }\end{array}$ & Material_zmin $=\ldots$ \\
\hline & & & $\begin{array}{l}\text { Material_ } \sigma \text { mechanical properties of the material (minimum } \\
\text { strength in the three dimensions) }\end{array}$ & Material_$\sigma=\ldots$ \\
\hline & & & $\begin{array}{l}\text { Material_Ra_xy: minimum obtainable roughness in xy plane } \\
\text { related to the material }\end{array}$ & Material_Ra_xy $=\ldots$ \\
\hline & & & $\begin{array}{l}\text { Material_tx, Material_ty, Material_tz: dimensional } \\
\text { tolerances related to the material }\end{array}$ & $\begin{array}{l}\text { Material_tx }=\ldots \\
\text { Material_ty }=\ldots \\
\text { Material_tz }=\ldots\end{array}$ \\
\hline \multirow[t]{2}{*}{ M3 } & \multirow[t]{2}{*}{ Slicing } & \multirow{2}{*}{$\begin{array}{l}\text { Material deposed } \\
\text { slice by slice }\end{array}$} & $\begin{array}{l}\text { Slicing_ox, Slicing_oy, Slicing_oz: mechanical properties } \\
\text { (minimum strength in the three dimensions) related to slicing }\end{array}$ & 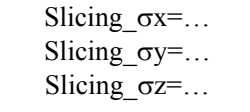 \\
\hline & & & $\begin{array}{l}\text { Slicing_Ra_z: minimum obtainable roughness in z direction } \\
\text { related to slicing }\end{array}$ & Slicing_Ra_z=... \\
\hline
\end{tabular}


Table 5. Parametric product features for plastic front covers

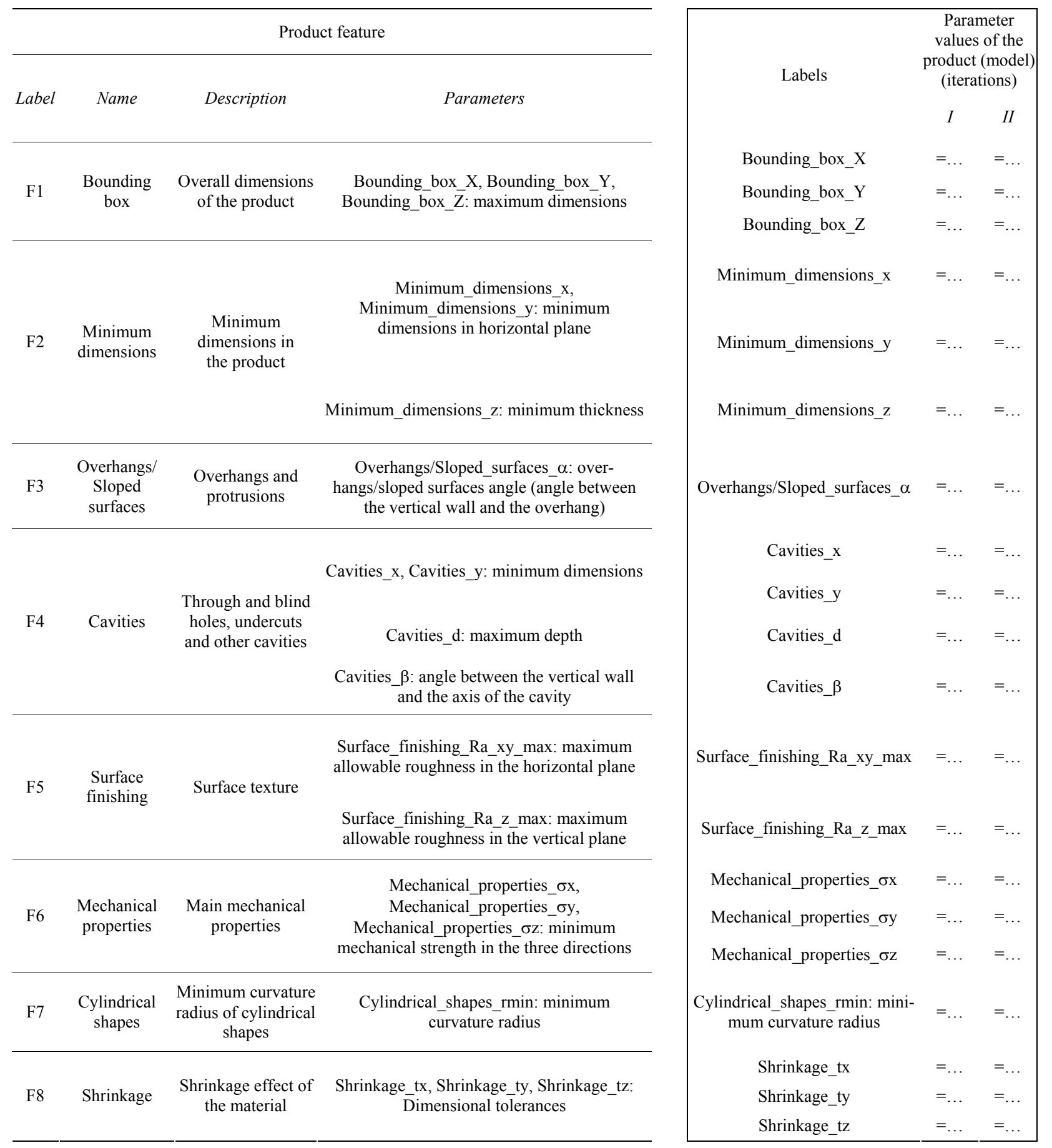

iterative way. The product (model) is analyzed for compatibility with the available technologies, some actions are performed and the resulting product (model) is processed from the beginning (new iteration).

Finally, Table 9, Table 10, Table 11, and Table 12 show the relations between the technological characteristics and the product features, expressed in a qualitative way, for each meaningful couple technology/product.

This result is important because, as stated in the section of the DGLs-CF overview, the following step of the DGLs-CF roadmap consists in generating the rules that will be the source of the actions to be performed on the product (model) to get the best compatibility. The values "Strong" and "Weak" drive the rule and action definition 
Table 6. Parametric product features for headlights

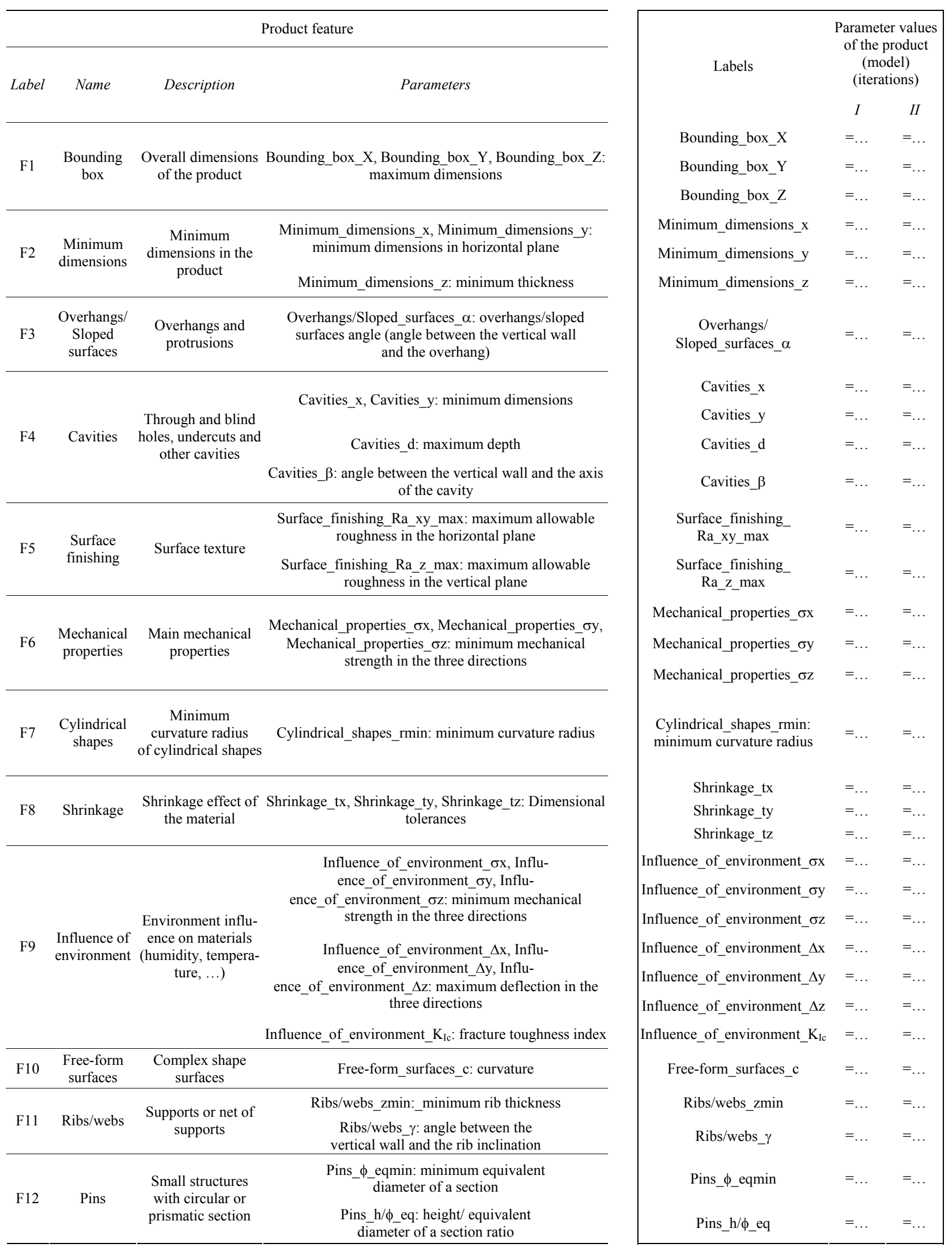


Table 7. Parametric product features for moulds for headlights

\begin{tabular}{|c|c|c|c|}
\hline \multicolumn{4}{|c|}{ Product feature } \\
\hline Label & Name & Description & Parameters \\
\hline $\mathrm{F} 1$ & Bounding box & $\begin{array}{l}\text { Overall dimensions } \\
\text { of the product }\end{array}$ & $\begin{array}{c}\text { Bounding_box_X, Bounding_box_Y, } \\
\text { Bounding_box_Z: maximum } \\
\text { dimensions }\end{array}$ \\
\hline $\mathrm{F} 2$ & $\begin{array}{l}\text { Minimum } \\
\text { dimensions }\end{array}$ & $\begin{array}{l}\text { Minimum dimen- } \\
\text { sions in the product }\end{array}$ & $\begin{array}{l}\text { Minimum_dimensions_x, } \\
\text { Minimum_dimensions_y: minimum } \\
\text { dimensions in horizontal plane } \\
\text { Minimum_dimensions_z: minimum } \\
\text { thickness }\end{array}$ \\
\hline F3 & $\begin{array}{l}\text { Overhangs/ } \\
\text { Sloped sur- } \\
\quad \text { faces }\end{array}$ & $\begin{array}{l}\text { Overhangs and } \\
\text { protrusions }\end{array}$ & $\begin{array}{c}\text { Overhangs/Sloped_surfaces_ } \alpha \text { : } \\
\text { overhangs/sloped surfaces angle } \\
\text { (angle between the vertical wall and } \\
\text { the overhang) }\end{array}$ \\
\hline $\mathrm{F} 4$ & Cavities & $\begin{array}{l}\text { Through and blind } \\
\text { holes, undercuts and } \\
\text { other cavities }\end{array}$ & $\begin{array}{l}\text { Cavities_x, Cavities_y: minimum } \\
\text { dimensions } \\
\text { Cavities_d: maximum depth } \\
\text { Cavities_ } \beta \text { : angle between the verti- } \\
\text { cal wall and the axis of the cavity }\end{array}$ \\
\hline F5 & $\begin{array}{l}\text { Surface } \\
\text { finishing }\end{array}$ & Surface texture & $\begin{array}{c}\text { Surface_finishing_Ra_xymax: } \\
\text { maximum allowable roughness in the } \\
\text { horizontal plane } \\
\text { Surface_finishing_Ra_zmax: } \\
\text { maximum allowable roughness } \\
\text { in the vertical plane }\end{array}$ \\
\hline F6 & $\begin{array}{l}\text { Mechanical } \\
\text { properties }\end{array}$ & $\begin{array}{c}\text { Main mechanical } \\
\text { properties }\end{array}$ & 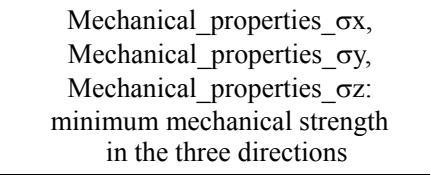 \\
\hline F7 & $\begin{array}{l}\text { Cylindrical } \\
\text { shapes }\end{array}$ & $\begin{array}{l}\text { Minimum curvature } \\
\text { radius of cylindrical } \\
\text { shapes }\end{array}$ & $\begin{array}{l}\text { Cylindrical_shapes_rmin: minimum } \\
\text { curvature radius }\end{array}$ \\
\hline F8 & Shrinkage & $\begin{array}{c}\text { Shrinkage effect of } \\
\text { the material }\end{array}$ & $\begin{array}{c}\text { Shrinkage_tx, Shrinkage_ty, } \\
\text { Shrinkage_tz: Dimensional } \\
\text { tolerances }\end{array}$ \\
\hline F9 & $\begin{array}{l}\text { Influence of } \\
\text { environment }\end{array}$ & $\begin{array}{l}\text { Environment influ- } \\
\text { ence on materials } \\
\text { (humidity, tempera- } \\
\text { ture, ...) }\end{array}$ & 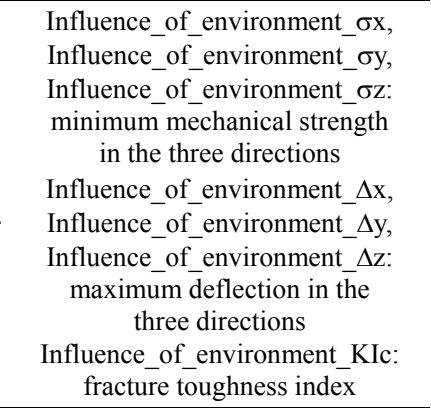 \\
\hline F10 & $\begin{array}{l}\text { Free-form } \\
\text { surfaces }\end{array}$ & $\begin{array}{l}\text { Complex shape } \\
\text { surfaces }\end{array}$ & Free-form_surfaces_c: curvature \\
\hline F11 & Pins & $\begin{array}{l}\text { Small structures } \\
\text { with circular or } \\
\text { prismatic section }\end{array}$ & $\begin{array}{c}\text { Pins_ } \phi \text { _eqmin: minimum equivalent } \\
\text { diameter of a section } \\
\text { Pins_h } / \phi \_ \text {eq: height/ equivalent } \\
\text { diameter of a section ratio }\end{array}$ \\
\hline
\end{tabular}

\begin{tabular}{|c|c|c|}
\hline \multirow[t]{2}{*}{ Labels } & \multicolumn{2}{|c|}{$\begin{array}{l}\text { Parameter value } \\
\text { of the product } \\
\text { (model) } \\
\text { (iterations) }\end{array}$} \\
\hline & $\mathrm{I}$ & II \\
\hline Bounding_box_X & $=\ldots$ & $=\ldots$ \\
\hline Bounding_box_Y & $=\ldots$ & $=\ldots$ \\
\hline Bounding_box_Z & $=\ldots$ & $=\ldots$ \\
\hline Minimum_dimensions_x & $=\ldots$ & $=\ldots$ \\
\hline Minimum_dimensions_y: & $=\ldots$ & $=\ldots$ \\
\hline Minimum_dimensions_z & $=\ldots$ & $=\ldots$ \\
\hline Overhangs/Sloped_surfaces_ $\alpha$ & $=\ldots$ & $=\ldots$ \\
\hline Cavities_x & $=\ldots$ & $=\ldots$ \\
\hline Cavities_y & $=\ldots$ & $=\ldots$ \\
\hline Cavities_d & $=\ldots$ & $=\ldots$ \\
\hline Cavities_ $\beta$ & $=\ldots$ & $=\ldots$ \\
\hline Surface_finishing_Ra_xymax & $=\ldots$ & $=\ldots$ \\
\hline $\begin{array}{c}\text { Surface_finishing } \\
\text { _Ra_zmax }\end{array}$ & $=\ldots$ & $=\ldots$ \\
\hline Mechanical_properties_ $\sigma \mathrm{x}$ & $=\ldots$ & $=\ldots$ \\
\hline Mechanical_properties_oy & $=\ldots$ & $=\ldots$ \\
\hline Mechanical_properties_oz & $=\ldots$ & $=\ldots$ \\
\hline Cylindrical_shapes_rmin & $=\ldots$ & $=\ldots$ \\
\hline Shrinkage_tx & $=\ldots$ & $=\ldots$ \\
\hline Shrinkage_ty & $=\ldots$ & $=\ldots$ \\
\hline Shrinkage_tz & $=\ldots$ & $=\ldots$ \\
\hline Influence_of_environment_ $\sigma x$ & $=\ldots$ & $=\ldots$ \\
\hline Influence_of_environment_ $\sigma y$ & $=\ldots$ & $=\ldots$ \\
\hline Influence_of_environment_ $\sigma z$ & $=\ldots$ & $=\ldots$ \\
\hline Influence_of_environment_ $\Delta \mathrm{x}$ & $=\ldots$ & $=\ldots$ \\
\hline Influence_of_environment_ $\Delta y$ & $=\ldots$ & $=\ldots$ \\
\hline Influence_of_environment_ $\Delta z$ & $=\ldots$ & $=\ldots$ \\
\hline Influence_of_environment_KIc & $=\ldots$ & $=\ldots$ \\
\hline Free-form_surfaces_c & $=\ldots$ & $=\ldots$ \\
\hline Pins_ф_eqmin & $=\ldots$ & $=\ldots$ \\
\hline Pins_h/ $/ \phi \_$eq & $=\ldots$ & $=\ldots$ \\
\hline
\end{tabular}


Table 8. Parametric product features for dashboards

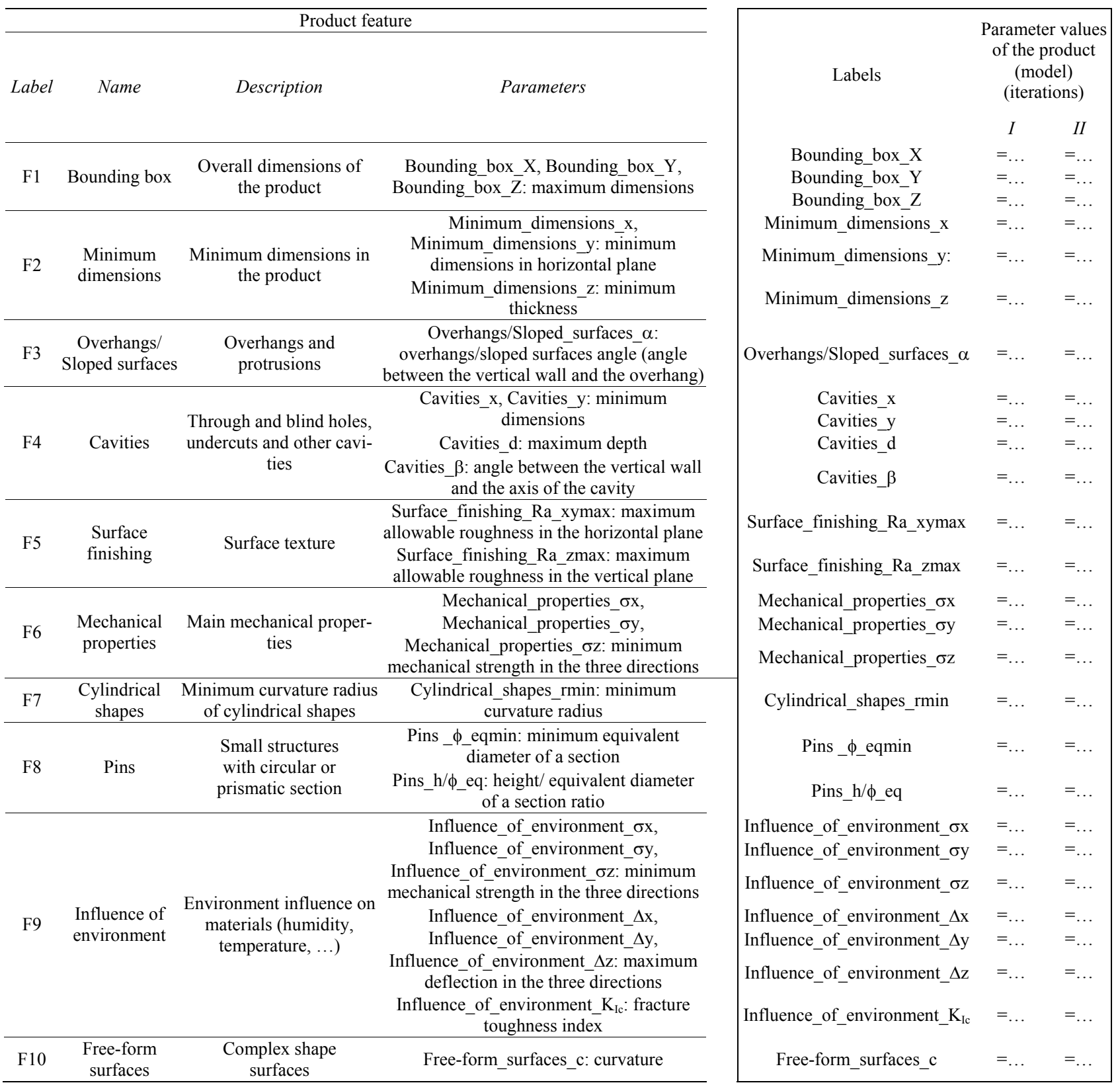

Table 9. Relations between FDM manufacturing characteristics and the product features for plastic front covers

\begin{tabular}{|c|c|c|c|c|c|c|c|c|c|}
\hline & & $\mathrm{F} 1$ & $\mathrm{~F} 2$ & F3 & F4 & F5 & F6 & F7 & F8 \\
\hline & & $\begin{array}{l}\text { Bounding } \\
\text { box }\end{array}$ & $\begin{array}{l}\text { Minimum } \\
\text { dimensions }\end{array}$ & $\begin{array}{l}\text { Overhangs/ } \\
\text { Sloped } \\
\text { surfaces }\end{array}$ & Cavities & $\begin{array}{l}\text { Surface } \\
\text { finishing }\end{array}$ & $\begin{array}{c}\text { Mechanical } \\
\text { properties }\end{array}$ & $\begin{array}{c}\text { Cylindrical } \\
\text { shapes }\end{array}$ & Shrinkage \\
\hline M1 & Workspace & Strong & & & & & & & \\
\hline M2 & Material & & Weak & & Weak & Weak & Strong & & Strong \\
\hline M3 & Slicing & & Strong & & Strong & Strong & Strong & Strong & Strong \\
\hline M4 & Support & & Strong & Strong & Strong & Weak & Weak & Weak & \\
\hline
\end{tabular}


Table 10. Relations between SLA manufacturing characteristics and the product features for headlights

\begin{tabular}{|c|c|c|c|c|c|c|c|c|c|c|c|c|c|}
\hline & & $\mathrm{F} 1$ & $\mathrm{~F} 2$ & F3 & F4 & F5 & F6 & F7 & F8 & F9 & F10 & F11 & F12 \\
\hline & & $\begin{array}{c}\text { Bounding } \\
\text { box }\end{array}$ & $\begin{array}{c}\text { Minimum } \\
\text { dimensions }\end{array}$ & $\begin{array}{l}\text { Overhangs/ } \\
\text { Sloped } \\
\text { surfaces }\end{array}$ & Cavities & $\begin{array}{l}\text { Surface } \\
\text { finishing }\end{array}$ & $\begin{array}{c}\text { Mechanical } \\
\text { properties }\end{array}$ & $\begin{array}{c}\text { Cylindrical } \\
\text { shapes }\end{array}$ & Shrinkage & $\begin{array}{l}\text { Influence of } \\
\text { environment }\end{array}$ & $\begin{array}{c}\text { Free-form } \\
\text { surfaces }\end{array}$ & $\begin{array}{l}\text { Ribs/ } \\
\text { webs }\end{array}$ & Pins \\
\hline M1 & Workspace & Strong & & & & & & & & & & & \\
\hline M2 & Material & & & & & Strong & Strong & & Weak & Strong & & & \\
\hline M3 & Slicing & & Strong & & Weak & Strong & Strong & Strong & & Weak & Strong & Strong & Strong \\
\hline M4 & Support & & Strong & Strong & Strong & Strong & & Weak & & & Strong & Strong & Strong \\
\hline M5 & $\begin{array}{l}\text { Building } \\
\text { style }\end{array}$ & & Weak & & Weak & Weak & Weak & Weak & Weak & Strong & Weak & & \\
\hline
\end{tabular}

Table 11. Relations between SLS manufacturing characteristics and the product features for moulds for headlights

\begin{tabular}{|c|c|c|c|c|c|c|c|c|c|c|c|c|}
\hline & & $\mathrm{F} 1$ & $\mathrm{~F} 2$ & F3 & F4 & F5 & F6 & F7 & F8 & F9 & F10 & F11 \\
\hline & & $\begin{array}{l}\text { Bounding } \\
\text { box }\end{array}$ & $\begin{array}{c}\text { Minimum } \\
\text { dimensions }\end{array}$ & $\begin{array}{l}\text { Overhangs/ } \\
\text { Sloped } \\
\text { surfaces }\end{array}$ & Cavities & $\begin{array}{l}\text { Surface } \\
\text { finishing }\end{array}$ & $\begin{array}{c}\text { Mechanical } \\
\text { properties }\end{array}$ & $\begin{array}{l}\text { Cylindrical } \\
\text { shapes }\end{array}$ & Shrinkage & $\begin{array}{l}\text { Influence of } \\
\text { environment }\end{array}$ & $\begin{array}{l}\text { Free-form } \\
\text { surfaces }\end{array}$ & Ribs/webs \\
\hline M1 & Workspace & Strong & & & & & & & & & & \\
\hline M2 & Material & & & & & Strong & Strong & Strong & & Strong & & \\
\hline M3 & Slicing & & Strong & & Weak & Strong & Strong & Weak & Strong & Weak & Strong & Strong \\
\hline M4 & Support & & Strong & Strong & Strong & Strong & & & Weak & & Strong & Strong \\
\hline M5 & $\begin{array}{c}\text { Building } \\
\text { style }\end{array}$ & & Weak & & Weak & Strong & Weak & Strong & Weak & Strong & Weak & \\
\hline
\end{tabular}

Table 12. Relations between LOM manufacturing characteristics and the product features for dashboards

\begin{tabular}{|c|c|c|c|c|c|c|c|c|c|c|c|}
\hline & & $\mathrm{F} 1$ & $\mathrm{~F} 2$ & F3 & $\mathrm{F} 4$ & F5 & F6 & F7 & F8 & F9 & F10 \\
\hline & & $\begin{array}{l}\text { Bounding } \\
\text { box }\end{array}$ & $\begin{array}{l}\text { Minimum } \\
\text { dimensions }\end{array}$ & $\begin{array}{l}\text { Overhangs/ } \\
\text { Sloped } \\
\text { surfaces }\end{array}$ & Cavities & $\begin{array}{c}\text { Surface } \\
\text { finishing }\end{array}$ & $\begin{array}{c}\text { Mechanical } \\
\text { properties }\end{array}$ & Cylindrical shapes & Pins & $\begin{array}{l}\text { Influence of } \\
\text { environment }\end{array}$ & $\begin{array}{c}\text { Free-form } \\
\text { surfaces }\end{array}$ \\
\hline M1 & Workspace & Strong & & & & & & & & & \\
\hline M2 & Material & & Strong & Weak & Strong & Strong & Strong & & & Strong & \\
\hline M3 & Slicing & & Weak & Weak & Strong & Weak & Strong & Strong & Strong & Weak & Strong \\
\hline
\end{tabular}

Table 13. Reconfiguration package for a headlight to be produced by SLA

\begin{tabular}{|c|c|c|c|c|c|c|c|}
\hline \multirow{5}{*}{$\begin{array}{c}\text { Reconfiguration } \\
\text { Package }\end{array}$} & \multirow[b]{2}{*}{ Domain } & \multicolumn{3}{|c|}{ Actions } & \multicolumn{3}{|c|}{ Relationships } \\
\hline & & Name & Goals & Cost & Features & $\begin{array}{l}\text { Technological } \\
\text { characteristics }\end{array}$ & Weight \\
\hline & Design & $\begin{array}{l}\text { Over-dimensi } \\
\text { on thin parts }\end{array}$ & $\begin{array}{l}\text { to make them } \\
\text { compatible with the } \\
\text { need for supports, the } \\
\text { slicing and the material }\end{array}$ & 8 & $\begin{array}{l}\text { Minimum } \\
\text { dimensions }\end{array}$ & $\begin{array}{c}\text { Slicing } \\
\text { Support } \\
\text { Building style }\end{array}$ & $\begin{array}{l}\text { Strong } \\
\text { Strong } \\
\text { Weak }\end{array}$ \\
\hline & Manufacturing & $\begin{array}{l}\text { Orient the } \\
\text { model }\end{array}$ & $\begin{array}{l}\text { to avoid the need for } \\
\text { support on surfaces } \\
\text { requiring best } \\
\text { roughness }\end{array}$ & 5 & Surface finishing & $\begin{array}{c}\text { Material } \\
\text { Slicing } \\
\text { Support } \\
\text { Building style }\end{array}$ & $\begin{array}{l}\text { Strong } \\
\text { Strong } \\
\text { Strong } \\
\text { Weak }\end{array}$ \\
\hline & Verification & $\begin{array}{l}\text { Rotate and } \\
\text { incline the } \\
\text { measuring } \\
\text { head }\end{array}$ & $\begin{array}{l}\text { to obtain best } \\
\text { accessibility to the } \\
\text { overhangs and } \\
\text { the minimum } \\
\text { re-positioning }\end{array}$ & 2 & $\begin{array}{l}\text { Overhangs/Sloped } \\
\text { surfaces }\end{array}$ & Support & Strong \\
\hline
\end{tabular}


by weighting the importance of the pieces of information inside the DGLs-CF data structure, thus leading to a more effective Redesign/Reconfiguration Package generation.

Table 13 shows an example of Redesign/Reconfiguration Package generated using the DGLs-CF during the redesign of a headlight to be built with SLA. The strongweak classification - degree of correlation - of the relationships between technological characteristics and product features has been exploited by the DGLs-CF algorithm used to generate this package. Moreover, the classification has been explicitly added to the package as a further help for the DGLs-CF users.

\section{Conclusions}

This paper describes the knowledge base enhancement and the knowledge management update of a method for product redesign and process reconfiguration named Design Guidelines - Collaborative Framework (DGLs-CF). Information collected using different strategies and from different sources (interviews, previous experiences, documentation, etc,) is formatted according to the data structure of this framework. These additional pieces of information enrich the knowledge base content of the method and make it tailored on the specific technologies. The specific characteristics of the RP technologies are in fact related to the product features and their relationships are weighted, thus allowing to privilege the actions determined by strong relationships in achieving the final result of the framework. Moreover, the analysis of these pieces of information suggested some interesting improvements of the knowledge management inside the DGLsCF. An example of application of the DGLs-CF is shown: the Redesign/ Reconfiguration Package - a list of actions to be performed on the product (model) and/or on the process to get the best compatibility between the product and the manufacturing technology - related to a headlight to be produced by SLA.

In the future the same activities will be used for gathering data related to other technologies. In the meantime, this work suggests to evaluate all the parameters in the four tables of the technologies with respect to those in the four tables of the product features. In doing this, the affinity between some classes of technologies and some classes of products coming from experience could be confirmed or not.

\section{Acknowledgments}

Authors would like to thank for her precious help Dr. Barbara Motyl, researcher at the DIEGM dept. of the University of Udine, Italy.

\section{References}

[1] F. Alizon, K. Khadke, H. J. Thevenot, J. K. Gershenson, T. J. Marion, S. B. Shooter, and T. W. Simpson, "Frameworks for product family design and development," Concurrent Engineering, Vol. 15, No. 2, pp. 187-199, 2007.

[2] D. M. Andersen, "Design for manufacturability \& concurrent engineering," Lafayette, CIM Press, CA, 2003.

[3] E. K. Antonsson \& J. Cagan, eds., "Formal engineering design synthesis," Cambridge University Press, Cambridge, UK, 2001.

[4] J. C. Borg, X. Yan, and N. P. Juster, "Exploring decisions' influence on life-cycle performance to aid 'design for Multi-X," Artificial Intelligence for Engineering Design, Analysis and Manufacturing, Vol. 14, pp. 91-113, 2000.

[5] J. P. Clarkson \& C. Eckert, (Eds.) "Design process improvement - a review of current practice," Springer, ISBN: 1-85233-701-X, 2005.

[6] C. L. Dym and P. Little, "Engineering design: A project-based introduction," Wiley and Sons, 2003.

[7] J. S. Gero, (eds.) "Artificial intelligence in design'02," Kluwer, Dordrecht, 2002.

[8] K. Otto \& K. Wood, Product Design, Prentice Hall. 2000.

[9] G. Pahl \& W. Beitz, "Engineering design: A systematic approach," Springer, 1995.

[10] D. Ullman, The Mechanical Design Process, Mac Graw Hill, 2002.

[11] K. T. Ulrich \& S. D. Eppinger, Product Design \& Development, Mac Graw Hill, 2000.

[12] S. Filippi \& I. Cristofolini, "The design guidelines (DGLs), a knowledge based system for industrial design developed accordingly to ISO-GPS (geometrical product specifications) concepts," Research in Engineering Design, Vol. 18, No. 1, pp. 1-19, 2007.

[13] R. M. Baecker, "Readings in groupware and computersupported cooperative work," San Francisco, CA, Morgan Kaufmann Publishers, Inc, 1993.

[14] R. Crabtree, M. S. Fox, and N. Baid, "Case studies of coordination activities and problems in collaborative design," Research in Engineering Design, Vol. 9, No. 2, pp. 70-84, 1997.

[15] A. H. B. Duffy, M. M. Andreasen, and F. J. O'Donnell, "Design co-ordination," Proceedings of International Conference on Engineering Design (ICED'99), Vol. 1, pp. 113-118, 1999.

[16] R. Houssin, A. Bernard, P. Martin, G. Ris, F. Cherrier, "Information system based on a working situation model for a new design approach in concurrent engineering," Journal of Engineering Design, Vol. 17, No. 1, pp. 35-54. 2006.

[17] H. Hung, H. Kao, and K. Ku, "Evaluation of design alternatives in collaborative development and production of modular products," the International Journal of Advanced Manufacturing Technology, Vol. 33, pp. 1065-1076, 2007.

[18] Y. E. Nahm \& H. Ishikawa, "Integrated product and process modeling for collaborative design environment," Concurrent Engineering, Vol. 12, No. 1, pp. 5-23, 2004. 
[19] P. Wilson, "Computer supported cooperative work: an introduction," Kluwer Academic Publishers, 1991.

[20] Z. Wu \& A. Duffy, "Mutual knowledge evolution in team design," Workshop on Learning and Creativity, 7th International Conference on Artificial Intelligence in Design (AID’02), Cambridge, UK, 2002.

[21] C. Bandera, I. Cristofolini, and S. Filippi, "Customizing a knowledge-based system for design optimization in fused deposition modeling RP-technique," AMST'05 Seventh International Conference on Advanced Manufacturing Systems and Technology, Springer Wien-New York, pp. 607-616, 2005.

[22] I. Cristofolini, S. Filippi, and C. Bandera, "How rapid prototyping process parameters could affect the product design phase: a KBS approach," Proceedings IDETC/CIE 2006 - ASME International Design Engineering Technical Conferences \& Computers and Information In Engineering Conference DETC 2006, Philadelphia, PA, ISBN 0-7918-3784-X, 2006.

[23] S. Filippi, C. Bandera, and G. Toneatto, "Generation and testing of guidelines for effective rapid prototyping activities," Proceedings of "XII ADM International Conference on Design Tools and Methods in Industrial Engineering”, Italy, 2001.

[24] "Draft federal information processing standards, FIPS PUB 183," Standard for Integration Definition for Function Modeling (IDEF0), National Institute of Standards and Technology, Gaithersburg, MD, USA, 1993.

[25] P. F. Jacobs, "Stereolithography and other RP\&M technologies," American Society of Mechanical Engineers, New York, 1996.

[26] D. T. Pham and S. S. Dimov, "Rapid manufacturing," Springer, Berlin Heidelberg, New York, 2001.

[27] I. Raja, I. Vinesh, I. Fernandes and J. Kiran, Reverse engineering - An industrial perspective," Spinger-Verlag London, 2008.

[28] P. S. Banerjee, A. Sinha, and M. K. Banerjee, "A study on effect of variation of SLA process parameters over strength of built model," Proceedings of the $2^{\text {nd }}$ National Symposium on Rapid Prototyping \& Rapid Tooling Technologies, pp. 79-84, 2002.

[29] H. S. Byun and K. H. Lee, "A decision support system for the selection of a rapid prototyping process using the modified TOPSIS method," the International Journal of Advanced Manufacturing Technology, Vol. 26, pp. 13381347, 2005.

[30] W. Cheng, J. Y. H. Fuh, A.Y. C. Nee, Y. S. Wong, and T. Miyazawa, "Multi-objective optimization of part building orientation in stereolithography," Rapid Prototyp Journal, Vol. 1, No. 4, pp. 12-23, 1995.

[31] K. Chockalingam, N. Jawahar, K. N. Ramanathan, and P. S. Banerjee, "Optimization of stereolithography process parameters for part strength using design of experiments," the International Journal of Advanced Manufacturing Technology, DOI 10.1007/ s00170- 004-2307-0, 2005.

[32] R. Harris, N. Hopkinso, H. Newlyn, R. Hague, and P. Dickens, "Layer thickness and draft angle selection for stereolithography injection mould tooling," International Journal of Production Research, Vol. 40, No. 3, pp. 719 $729,2002$.

[33] I. Horv'ath, J. J. Broek, Z. Rus'ak, G. Kuczogi, and J. S. M. Vergeest, "Morphological segmentation of objects for thick-layered manufacturing," Proceedings of the 1999 ASME Conference on Design for Manufacturing," Las Vegas, pp. 18-24, 1999.

[34] S. H. Masood and A. Soo, "A rule based expert system for rapid prototyping system selection," Robot Computer Integrated Manufacturing, Vol. 18, pp. 267-274, 2002.

[35] X. Qian and D. Dutta, "Feature based fabrication in layered manufacturing," Transactions on ASME Journal Mechanism Design, Vol. 123, No. 3, pp. 337-345, 2001.

[36] A. Rosochowski and A. Matuszak, "Rapid tooling: The state of the art," Journal of Materials Processing Technologies, Vol. 106, pp. 191-198, 2000.

[37] Y. Tang, H. T. Loh, J. Y. H. Fuh, Y. S. Wong, and S. H. Lee, "An algorithm for disintegrating large and complex rapid prototyping objects in a CAD environment," International Journal of Advanced Manufacturing Technology, Vol. 25, 895-901, 2005.

[38] R. E. Williams, S. N. Komaragiri, V. L. Melton, R. R. Bishu, "Investigation of the effect of various build methods on the performance of rapid prototyping (stereolithography)," Journal of Materials Processing Technology, Vol. 61, pp. 173-178. 1996. 